\title{
Práticas inovadoras para biblioteca escolar
}

\author{
Innovative practices for school library
}

Eduardo Silveira

Doutorando em Ciência da Informação pelo Programa de Pós-Graduação da Universidade Federal de Santa

Catarina - UFSC.

E-mail: edusilveira1985@gmail.com

\section{BLATTMANN, Ursula; VIANNA, William Barbosa (Org.). Inovação em escolas com}

bibliotecas. Florianópolis: Dois por Quatro, 2016. ISBN 978-85-69609-03-2.

A escola sempre está propícia a ações inovadoras, pois nela a informação e o conhecimento podem circular de vários modos, fazendo com que a aprendizagem se transforme no maior insumo para cada indivíduo que a frequenta.

Quando a escola possui bibliotecas, a informação, o conhecimento e a aprendizagem podem fluir com mais eficiência e dinamismo. Isto é o que apresenta a obra "Inovação em escolas com bibliotecas” dos organizadores Ursula Blattmann e Willian Barbosa Vianna.

A professora Ursula Blattmann é pós-doutora em Ciência da Informação e atua no departamento de Ciência da Informação na Universidade Federal de Santa Catarina, ademais é líder do Instituto de pesquisa Biblion e editora da revista Ágora. O professor William Barbosa Vianna é doutor em Engenharia de Produção e atua também no departamento de Ciência da Informação na respectiva universidade, onde é coordenador do grupo de pesquisa Gestão Estratégica da Informação, Empreendedorismo e Inovação.

O livro foi lançado no segundo semestre de 2016 pela editora Dois por Quatro, fazendo parte da série "Educação e Informação". O resultado do trabalho é uma parceria do Instituto de Pesquisa Biblion e do Laboratório de Estudos em Biblioterapia, Bibliotecas Escolares e Leitura, ambos da Universidade Federal de Santa Catarina. Os autores reuniram 23 coautores distribuídos em 13 capítulos.

No capítulo um, Bedin, Sena e Chagas alinham o tema competência informacional e biblioteca escolar. As autoras discutem ações que podem ser desenvolvidas no ambiente da escola e biblioteca, dentre elas estão ações em diversas perspectivas como a infraestrutura do lugar, a atualização do acervo, a presença do bibliotecário, atividades de pesquisa, mediação de leitura e inserção de tecnologias. 
A atuação do bibliotecário escolar no setor infantil de uma biblioteca mista é o tema central do capítulo dois. Silva e Hillesheim adentram no perfil do bibliotecário escolar em uma biblioteca mista, composta por dois tipos de público, alunos da educação básica (escolar) e alunos do ensino superior (universitária). Por se tratar de dois tipos de público, o perfil do bibliotecário nem sempre atende as necessidades de ambos, no caso da biblioteca escolar são elencados a empatia de trabalhar com o público infantil, a identificação das necessidades informacionais e de leitura dos usuários, bem como as habilidades desenvolvidas pelo bibliotecário.

O capítulo três discute sobre a brinquedoteca em bibliotecas escolares, das autoras Caldin e Borges. A brinquedoteca pode ser um agente de mudança do ponto de vista educacional, pois a associação do brinquedo ao livro pode ser um atrativo para o hábito de leitura, o desenvolvimento e o aprendizado da criança. O capítulo apresenta também as definições de brinquedoteca, o histórico e a legislação vigente no Brasil, bem como os aspectos do brincar no processo de aprendizagem.

As atividades lúdicas dentro da biblioteca escolar são a pauta principal do capítulo quatro. Assinado por D'Ávila e Fachin, o capítulo contempla biblioteca escolar, atividade lúdica e o lúdico literário. As autoras enfatizam a importância da biblioteca escolar, enfatizando que a mesma não seja apenas um complemento didático, e sim um ambiente de atividades lúdicas e de incentivo à leitura. As atividades lúdicas despertam o potencial cognitivo da criança, além de sua identidade e autonomia, bem como instigam a prática da leitura.

O capítulo cinco apresenta o universo do acervo fotográfico em bibliotecas escolares. Biff e Medeiros procuram apresentar uma proposta de organização de acervo fotográfico para bibliotecas escolares baseado em metodologias de representação descritiva e representação temática. Enfatizam que não é simples representar descritivamente materiais fotográficos, pois os mesmos não apresentam os elementos necessários para a descrição. O mesmo vale no que diz respeito também aos dois tipos de representações que inferem na atenção de representar um objeto visual de forma verbal.

Severino e Bedin dissertam sobre o bibliotecário como disseminador da informação em escolas. O capítulo seis levanta uma reflexão sobre a importância do bibliotecário e a biblioteca escolar sendo uma ponte para os alunos adquirirem e compartilharem novos conhecimentos. O bibliotecário com suas competências pode proporcionar na escola o acesso a informações 
pertinentes para a necessidade informacional de cada indivíduo, bem como contribuir com atividades educativas para o processo de ensino e aprendizagem.

O capítulo sete discorre sobre a ação cultural em bibliotecas escolares. Batista, Pinto e Araújo pesquisaram o impacto da ação cultural nas bibliotecas na cidade de Tubarão e Capivari de Baixo, Santa Catarina. O incentivo à leitura e às práticas culturais e artísticas contribui para a formação social e promovem cidadania. A ação cultural aplicada nas bibliotecas tem como ponto de partida a Semana Nacional do Livro e da Biblioteca, nela foram desenvolvidas várias atividades e parcerias, com a promoção de palestras com escritores, ciranda de poesias, contação de histórias e exposições. Para saber o impacto dessas atividades, as autoras produziram um questionário para a equipe pedagógica, professores e coordenadores das unidades.

A mediação de leitura promovida pela biblioteca escolar aos alunos do ensino fundamental foi pauta do capítulo oito. Oss-Emer, Trevisol Neto e Chagas trazem a importância do incentivo à leitura no ambiente escolar, visto que para muitas crianças essa prática só se inicia dentro da escola. Os autores salientam que este ambiente tem papel fundamental na formação do leitor e que a leitura deve ser estimulada por professores de todas as disciplinas, junto dos bibliotecários e da biblioteca escolar.

O capítulo nove aborda a conservação de obras no ambiente escolar. Bahia e Blattmann afirmam que o tema conservação de obras e biblioteca escolar na grande maioria dos casos não é discutido e que o bibliotecário tem papel principal na interlocução e cuidado na conservação de um acervo. As autoras apresentam algumas formas de como preservar as obras de microorganismos, insetos e roedores, bem como as rotinas de restauração de limpeza, pequenos reparos e a recuperação de encadernações. Ademais as formas de conservação são elencadas, alertando-se para o manuseio adequado da obra, a climatização do ambiente e o controle de poluentes.

A avaliação das fontes de informação em bibliotecas escolares é o que norteia o capítulo 10. Após uma breve contextualização de fontes de informação, Fachin e Blattmann destacam a importância de saber para quem as fontes de informação são designadas, pois cada usuário tem sua necessidade de informação, bem como cada biblioteca escolar tem sua característica. Quanto a avaliação, as autoras enfatizam que é preciso considerar na avaliação diversas questões, formatos e públicos, apresentando critérios de avaliações das fontes. 
No capítulo 11 é apresentado a literatura científica sobre a gestão de bibliotecas nas escolas. Vianna, Blattmann e Silveira identificam um portfólio bibliográfico da temática por meio de um instrumento (Knowledge Development Process - Constructivist (ProKnow-C)). A análise teve como foco a literatura nacional no Portal de Periódicos CAPES (nas bases Web of Science, Scopus, Ebsco e Lisa) e nas bases BRAPCI e BENANCIB, resultando assim em um portfólio com 18 artigos pertinentes à temática.

A Biblioteca Escolar do Trabalho é o tema principal do capítulo 12. Gehrke e Bufrem abordam esse tipo de biblioteca, e afirmam que esta é constituída por quatro matrizes formativas que interligam: a cultura, o conhecimento, a organização coletiva dos sujeitos e o trabalho.

Por fim, o último capítulo da obra, de autoria dos organizadores do livro, Blattmann e Vianna, tem como proposta a inovação em escolas com bibliotecas. No capítulo 13 os autores apresentam os conceitos de estratégia e inovação, ligando-os às bibliotecas escolares, aos desafios futuros de inovação em escolas com bibliotecas, como a promoção de leitura nesses ambientes, a criação de bibliotecas em escolas e a escolaridade dos indivíduos. O ambiente da internet também é pauta do capítulo, visto que a evolução dos livros também teve o suporte da rede para a disseminação da informação, ademais são recomendados diversos websites que disponibilizam diversas obras de acesso livre à população.

Com essa tamanha conjuntura, a obra não tão somente é recomenda apenas para profissionais diretamente ligados a biblioteca escolar, mas também para todos os profissionais da informação e comunidade em geral, pois o tema da inovação em escolas com bibliotecas é diversificado e diferenciado em cada capítulo, mostrando que existem várias formas para inovar nesses ambientes informacionais. 